(C) Kaskova L. F., Mandziuk T.B., Ulasevych L.P., Korovina L.D.

UDC: $616.314-002: 614$

DOI https://doi.org/10.31718/mep.2019.23.3-4.03

\title{
CORRELATION RELATIONS OF CARISES AND SOCIO-HYGIENIC FACTORS
}

\author{
${ }^{1}$ Kaskova L. F., ${ }^{2}$ Mandziuk T.B., ${ }^{1}$ Ulasevych L.P., ${ }^{1}$ Korovina L.D. \\ ${ }^{1}$ Ukrainian Medical Stomatological Academy, Poltava \\ ${ }^{2}$ Higher State Educational Establishment of Ukraine "Bukovinian State Medical University"
}

Нами було проведено статистичну обробку із застосуванням кореляційного аналізу даних анкетування та об'єктивного обстеження дітей та анкетування батьків з метою їх обізнаності з точки зору профілактики карієсу та способу життя. Результати показали, що на виникнення карієсу у дітей 7-12 років мають вплив соціально-гігієнічні фактори. Під час анкетування батьків виявлена дія сукупності чинників: відсутність звернення до лікаря стоматолога з метою профілактики, чистки зубів, нехтування додатковими предметами і засобами гігієни та неінформованість про них, регулярність і збалансованість харчування, недостатня поінформованість щодо причин виникнення карієсу, відсутність медичної інформації про це, звернення до лікаря лише при наявності больових відчуттів, тривожність під час відвідування лікаря-стоматолога. Анкетування дітей показало вплив сукупності факторів на виникнення карієсу, серед яких відсутність звернення до лікаря стоматолога з метою профілактики, недостатня поінформованість щодо причин виникнення карієсу, звернення до лікаря-стоматолога лише при наявності больових відчуттів, тривожність під час відвідування лікаря-стоматолога, недостатня інформованість про предмети і засоби гігієни порожнини рота. Сукупний вплив батьківської інформованості та батьківських звичок на розвиток карієсу у дітей значно вищий, ніж вплив відповідних особливостей дітей. Отже, аналіз чинників виникнення карієсу у дітей 7-12 років показав наявність тісних зв'язків між аліментарними, поведінковими звичками батьків і відповідними звичками дітей та розвитком патологічних змін у стані ротової порожнини дітей, що, в свою чергу, призводить до поширення каріозних уражень. Це вимагає посилення профілактичної роботи з батьками, спрямованої на формування у них здорових навичок способу життя та догляду за ротовою порожниною з метою запобігання порушень стану ротової порожнини та зубощелепного апарату.

Ключові слова: діти, карієс, чинники, кореляційний аналіз, критерій Манна-Уїтні, коефіцієнт парної кореляції Спірмена.

There is a demand in statistical processing of questionnaire data and objective screening of children with the usage of correlation analysis as well as interview with parents in order to increase their awareness about caries prevention and lifestyle. The emergence of caries in children 7-12 years of age is influenced by socio-hygienic factors. During the interview with parents, the effect of a combination of factors was found (i.e. avoiding referring to a dentist for the purpose of prevention or professional hygiene, neglecting the additional hygienic tools and methods and low awareness about them, regularity and balance of nutrition, lack of awareness concerning etiology of caries appearance, referring to a dentist only in case of toothache, anxiety during a visit to a dentist. Interview with children showed the impact of a combination of factors on the occurrence of caries. Among them are evasion of referring to a dentist for the purpose of prevention, lack of awareness concerning etiology of caries appearance, referring to a dentist only in case of toothache, anxiety during a visit to a dentist, low awareness concerning additional hygienic tools and methods. The combined effect of parental awareness and habits on the development of caries in children is much higher than the effect of the respective peculiarities of children. Thus, the analysis of caries appearance factors in children aged 7-12 years reveals the existence of close relationships between the alimentary, behavioral habits of parents and the appropriate habits of children and the development of pathological changes in the oral cavity of children which leads to the propagation of carious lesions. This requires improvement of preventive work with parents aimed at formation of healthy lifestyle habits and oral health care in order to prevent pathology of oral cavity and masticatory apparatus.

Key words: children, caries, factors, correlation analysis, Mann-Whitney $U$ test, Spearman's rank correlation coefficient

\section{Introduction}

Numerous data on the significance and influence of various risk factors on the development of caries in temporary and permanent teeth are represented in scientific literature sources. Records about the impact of various sociohygienic factors are represented in an isolated manner without consideration of children's age [1, 2, 3]. An insignificant volume of data on the relationship between the influence of factors on the part from the parents and their children side [4]. According to this, there is a demand in statistical processing of questionnaire data and objective screening of children with the usage of correlation analysis as well as interview with parents in order to increase their awareness about caries prevention and lifestyle.
This work is a part of research projects entitled "Improvement of prevention and treatment methods for major diseases of hard tissues of tooth and periodontium in children with risk factors", state registration № 0111U006760; "Improvement of prevention and treatment methods for major diseases of hard tissues of tooth and periodontium in children against the background of somatic pathology, considering the socio-economic factors and psycho-emotional state" (currently undergoing the registration process).

\section{Materials and methods}

We held a dental clinical-and-laboratory examination (determination of caries intensity, hygienic indexes according to Fedorov-Volodkina and Green-Vermillion, sa-

To cite this english version: L. F. Kaskova, T.B. Mandziuk, L.P. Ulasevych, L.D. Korovina. Correlation relations of carises and sociohygienic factors. // The Medical and ecological problems. - 2019. - Vol 23, № 3-4. - P. 9-12. 
liva secretion speed, saliva viscosity, $\mathrm{pH}$, determination of oral fluid microcrystallization, enamel resistance test) and interview with 223 children aged 7-12 years as well as interview with their parents.

Also performed a standarted statistical evaluation of the quantitative indicators obtained during the examination of patients. Statistical significance of differences in the results obtained from different groups of data with normal distribution was determined using Student's $t$ distribution test.

The significance of differences in the distribution of semi-quantitative and qualitative indicators was determined by the non-parametric Mann-Whitney $U$ test $[5,6$, 7]. Interrelations of indicators was estimated by Spearman's rank correlation coefficient, since a significant number of indicators were semi-quantitative and qualitative. Correlation coefficient was considered significant in the case of the probability of error $p<0.05[7,8]$.

\section{Results}

We found that the index of tooth caries for temporary and permanent teeth $(D E F+d f)$ has straight correlation relations with the hygiene index by Fedorov-Volodkina $(R=0.56, p<0.001)$, Green-Vermillion's hygiene index $(R=0.50, p<0.001)$, with the viscosity $(R=0.80)$, with the enamel resistance test $(R=0.76, p<0.001)$ and reversed correlation relations with saliva secretion speed ( $R=-0.55, p<0.001), p H(R=-0.66, p<0.001)$, microcrystallization $(R=0.85, p<0.001)$ and with prophylactic aimed visits with a dentist $(R=0.16, p<0.001)$.

We also found correlation dependences of the caries prevalence in children with individual hygienic and alimentary factors. There is a straight dependence with the usage of hygienic oral elixirs $(R=0.14, p<0.05)$, complaints about the condition of hard tooth tissues $(R=0.18$, $p<0.05)$, the presence of abnormally located teeth $(R=0.15, p<0.05)$. There is a reversed dependence on the preventive examinations at the dentist $(R=-0.16$, $p<0.05)$, gingival color change $(R=-0.21, p<0.002)$, with gum swelling $(R=-0.16, p<0.02)$.

A significant part of children while selecting a toothpaste takes into account its appearance. While choosing a toothbrush they pay attention on its stiffness, head size, shape and price.

Negative correlations of tooth caries prevalence in children with their awareness of oral cavity care from television, scientific-and-popular literature and friends were discovered $(R=0.16, p<0.05, R=0.14, p<0.05$, $R=0.23, p<0.002$, respectively). However, no interrelation with information from parents and doctors was found. There is also a direct correlations of tooth caries development in children with their behavioral features and social factors such as place of their residence (living in rural areas, $R=0.21, p<0.005)$, anxiety during a visit to a dentist $(R=0.18, p<0.01)$, visits to a tutor $(R=0.16$, $p<0.02)$, attendance of school circles $(R=0.24$, $p<0.001)$, attempts to smoke or drink alcohol $(R=0.19$, $p<0,01)$. There is a negative correlation with the frequency of prophylactic visits of dentist $(R=-0.16$, $p<0.02)$, with attendance of sports sections $(R=-0.14$, $p<0.05)$, presence of personal computer at home $(R=-0.14, p<0.05)$, with long-term preparation of homework $(R=-0.16, p<0.02)$.

We performed a multiple correlations analyzis of tooth caries manifestations in temporary and permanent teeth among children aged 7-12 years with factors that could affect the presence of clinical factors ( 7 factors) and socio-hygienic factors (50pcs. from the children's questionnaires and $37 \mathrm{pcs}$. from the parents' questionnaires).

The study of multiple relationships of tooth caries severity in children with clinical factors revealed that there are 3 most significant ones: microcrystallization, oral fluid viscosity and acidity resistance of tooth enamel, which form multiple regressive dependence with the correlation coefficient $R=0.84(p<0.001)$. The most significant factor is the oral fluid viscosity $(\beta=0.40)$. Microcrystallization has the second most important influence $(\beta=-0.35)$ and the acidity resistance of tooth enamel goes third $(\beta=0.17)$. This means that increasing viscosity and reducing microcrystallization contribute to the tooth caries development. An increase in the tooth enamel resistance test index also explains aggravation of the pathological process.

Each of clinical factors mentioned above has the correlation with a number of social-and-hygienic factors.

The oral fluid microcrystallization index is influences by the following factors revealed during the parents interrrogation: neglection of preventive visits to a dentist, neglection of additional tools and methods for oral hygiene by parents, absence of professional hygiene, lack of medical awareness regarding prevention methods and choice of hygienic tools and methods, with anxiety during dentist visiting. An additional group of factors was found according to children interrrogation. They were children's age, their neglecting the additional hygienic tools and methods, lack of knowledge concerning their choice. The conjoined effect of these factors is high $(R=0.70$, $\mathrm{p}<0.001$ ).

The acid resistance of teeth $(R=0.71, p<0.001)$ depends on the influence of such factors from the children's side as their age, place of residence (countryside), frequency of visits to the dentist for preventive measures, abnormal shape of teeth, the consumption of food rich on calcium, lack of medical awareness concerning prevention, carbonated beverages consumption, attempts of alcoholic tasting. Related factors after interview with parents are: age, frequency of visits to a dentist for prevention purpose, tooth brushing, absence of professional hygiene, lack of medical awareness concerning tooth caries appearance reasons and selection of hygienic tools and methods, anxiety during a visit to a dentist, appeal to a dentist in case of a toothache, physical training and sport.

The viscosity of oral fluid in children is also associated with a number of factors $(R=0.68, p<0.001)$. According to the results of interview with children, such factors as absence of preventive examinations, avoiding of additional hygienic tools and methods usage, lack of knowledge of approaches to their choice, presence of abnormal shaped teeth, changes gums color, lack of medical awareness concerning tooth caries appearance reasons, anxiety during a visit to a dentist affect oral fluid viscosity. Factors found after interview with parents are social status, avoiding of attending dentist for the prevention purpose by parents, tooth brushing, usage of additional hygienic tools and methods and lack of knowledge about them, anxiety during a visit to a dentist.

Otherwise, the multiple correlation dependence with the tooth caries severity is formed by the other 3 clinical factors such as saliva secretion rate, hydrogen index of oral fluid and the hygienic index by Fedorov-Volodkina. They form the multiple regression dependence with the correlation coefficient $R=0.74$ ( $p<0.001)$.

The most significant factor in this group is the hydrogen index of oral fluid $(\beta=-0.47)$. The second most sig- 
nificant effect on tooth caries appearence has the salivation rate $(\beta=-0.28)$ and the hygienic index $(\beta=0.18)$. This means that the decreasion of saliva secretion rate and the $\mathrm{pH}$ of oral fluid contribute to the development of caries. An increase of the hygienic index also indicates an aggravation of this process.

A similar regression dependence $(R=0.73)$ can be formed if the Green-Vermillion's hygienic index will replace Fedorov-Volodkina index in the group of factors. The hygiene indices by Green-Vermillion and FedorovVolodkina are correlate one with another in the group of junior children $(R=0.70(p<0.001))$ and in the group of senior children $(R=0.56(p<0.001))$.

Each of the clinical factors also has correlation with a number of socio-hygienic factors.

Thus, we see formed multiple regression dependence of Green-Vermilion's index in children $(R=0.48$, $p<0.001$ ) with the following factors (according to interview with parents): usage of additional hygiene tools and methods, correct choice of a toothbrush, parents visiting of a dentist for a preventive measure, parents smoking, their awareness concerning oral hygiene caere, age of parents (less younger parents, less attention to children), parents toothbrushing.

Saliva secretion rate in children has a multiple correlation $(R=0.47, p<0.001)$ with parents toothbrushing, their awareness of a toothbrush choice, bubblegum usage, sports occupation (parental occupation), appeals to a dentist concerning toothache appearance, lack of awareness about tooth caries prevention methods (regular visits to a dentist, regular brushing of teeth, rational nutrition).

Significant cumulative effect of a large group of indicators $(R=0.76, p<0.001)$ on oral fluid $p H$ of children's were found. Those indicators are family income, parents age, low parents' awareness concerning hygienic tools and methods choice (toothbrush size and shape selection), parents toothbrushing, parents neglection of additional hygienic tools and methods as well as neglection of consumption of food rich on calcium.

This group also includes the age of children, behavior specifications of children (attempts to alcohol consumption), neglecting the additional hygienic tools and methods by children, the presence abnormal shaped teeth, tooth color change, pain in gums, frequent consumption of snacks (e.g. potato chips), ignorance of dental diseases prevention possibility, substantial time spent at PC.

These two above-described groups of multiple correlations of caries prevalence have common causative factors. Hence, factors have significant pair correlations, which means that an attempt to form a common regression dependence does not increase the coefficient of multiple correlation more than $\mathrm{R}=0.84$ and the partial coefficients of half of the indices lose their statistical significance.

Such close relations that are also confirmed by the factor analysis in which all clinical factors (i.e. caries intensity, microcrystallization, oral fluid viscosity, acid resistance of tooth enamel, saliva secretion rate, hydrogen index of saliva and hygienic indices) form only one factor that absorbs the great portion of dispersion (64\%).

This is the consequence of close correlations between all indicators of the oral cavity condition. It indicates the existence of common factors that affect all identified changes. (Tab.)

Correlation coefficients of clinical parameters $(n=223)$

\begin{tabular}{|l|c|c|c|c|c|c|c|}
\hline \multicolumn{1}{|c|}{ Parameters } & $\begin{array}{c}\text { Hygienec } \\
\text { index } \\
\text { by Fedorov- } \\
\text { Volodkina }\end{array}$ & $\begin{array}{c}\text { Hygienec } \\
\text { index } \\
\text { by Green- } \\
\text { Vermilion }\end{array}$ & $\begin{array}{c}\text { Saliva } \\
\text { secretion } \\
\text { rate }\end{array}$ & $\begin{array}{c}\text { Acid } \\
\text { resistance } \\
\text { of tooth } \\
\text { enamel test }\end{array}$ & pH level & $\begin{array}{c}\text { Microcrystal- } \\
\text { lization }\end{array}$ & $\begin{array}{c}\text { Saliva } \\
\text { viscosity }\end{array}$ \\
\hline $\begin{array}{l}\text { Hygienic index by } \\
\text { Fedorov-Volodkina }\end{array}$ & - & 0.55 & -0.50 & 0.65 & -0.40 & -0.46 & 0.53 \\
\hline $\begin{array}{l}\text { Hygienic index by } \\
\text { Green-Vermilion }\end{array}$ & 0.55 & - & -0.42 & 0.55 & -0.47 & -0.52 & 0.60 \\
\hline $\begin{array}{l}\text { Saliva secretion } \\
\text { rate }\end{array}$ & -0.50 & -0.42 & - & -0.65 & 0.40 & 0.50 & -0.62 \\
\hline $\begin{array}{l}\text { Acid resistance of } \\
\text { tooth enamel test }\end{array}$ & 0.65 & 0.55 & -0.65 & - & -0.58 & -0.70 & 0.78 \\
\hline pH level & -0.40 & -0.47 & 0.40 & -0.58 & - & 0.78 & -0.63 \\
\hline Microcrystallization & -0.46 & -0.52 & 0.50 & -0.7 & 0.78 & - & -0.79 \\
\hline Saliva viscosity & 0.53 & 0.60 & -0.62 & 0.78 & -0.63 & -0.79 & - \\
\hline
\end{tabular}

Note: all of stated correlation coefficients have a statistical significance $p<0.001$.

The analysis of the combined effect of social factors on caries expression revealed the noticeable relationship $(R=0.84, p<0.001)$ of a large group of 41 factors which were determined by interview with parents, and much lower ( 6 factors) indicated by children $(R=0.48, p<0.001)$.

This fact clearly indicates the urgent need for preventive work with parents, focused on developing healthy lifestyle and oral care skills, which influences the formation of skills in maintaining healthy oral cavity in children more efficiently than working with children only.

\section{Conclusions}

The development of caries in children aged 7-12 years is influenced by socio-hygienic factors. During the interview with parents, the combination of factors was found (i.e. avoiding referring to the dentist for the purpose of prevention or professional hygiene, neglecting the additional hygienic tools and methods, low awareness about them, regularity and balance of nutrition, lack of awareness concerning etiology of caries appearance, referring to the dentist only in case of toothache, anxiety during the visit to the dentist.

Interview with children showed the impact of a combination of factors on the occurrence of caries. Among them are: avoiding the referral to the dentist for the purpose of prevention, lack of awareness concerning etiology of caries appearance, referring to the dentist only in case of toothache, anxiety during the visit to the dentist, low awareness concerning additional hygienic tools and methods. The combined effect of parental awareness and habits on the development of caries in children is 
Tom 23, N 3-4 2019 p.

much higher than the effect of the respective peculiarities of children.

Thus, the analysis of factors in caries development in children aged 7-12 years reveals the existence of close relationships between the alimentary, behavioral habits of parents and the appropriate habits of children and the development of pathological changes in the oral cavity of children which leads to the spread of carious lesions. This requires improvement of preventive work with parents aimed at formation of healthy lifestyle habits and oral health care in order to prevent pathology of the oral cavity and masticatory apparatus.

\section{References}

1. Yerem TV, Varga MD Influence of ecological-and-hygienic factors on dental caries disease in inhabitants of different biogeochemical zones of Transcarpathia. Scientific
Bulletin of Uzhgorod University. Series Medicine. 2015;1(51):190-194.

2. Smoliar NI, Chukhrai NL Interconnection of the oral cavity hygienic state with the activity of tooth caries in schoolage children. Modern Dentistry. 2015;2:46-49.

3. Cherepiuk OM, Musii-Semenetsiv $\mathrm{KhH}$ Assessment of risk factors for caries of temporary teeth in children. Bulletin of Biology and Medicine. 2016;1(1):380-383.

4. Cherepiuk OM, Stadnik UO Hygiene of the oral cavity and the level of sanitary-hygienic knowledge and skills in preschool children and their parents in Ivano-Frankivsk. Bulletin of Biology and Medicine. 2015;1(3):385-388.

5. Glants S. Medical-and-biological Statistics. Trans. from english. M.: Practice; 1998. 459.

6. Gubler E.V. Computational methods for the recognition of pathological processes. L.: Medicine, 1970. 319.

7. Borovikov V.P. The art of analyzing data on a computer (for professionals). 3rd edition. St. Petersburg, 2003. 688. Матеріал надійшов до редакції 05.04.2019 p. 